\title{
The Quality of Lower Secondary Students' Discussions During Labwork in Chemistry
}

\author{
Olle Eskilsson \\ Kristianstad University, Kristianstad, SWEDEN
}

Received 10 September 2007; accepted 19 February 2008

\begin{abstract}
The aim of this project is to study the quality of the discussions in groups of students during laboratory work. The project builds on a study of the role of communication in science classrooms with students aged 14-15 years. An intervention with role-playing for example reporting to another group is carried out to foster discourses that focus students' use of science knowledge. The discussions have been divided into sequences. In each sequence the students are discussing one separate part of the lab work activity. A revised version of the SOLO-taxonomy has been used in the analysis of tape recordings from students' discussions during lab work and from the reporting to another group. The students talk about the experimental procedure as well as the science content. In most of the groups the analysis show a long-term development towards higher quality mixed with unistructural sequences. During the reporting to another group the students describe the experiment using new knowledge and new concepts. Almost all the reporting groups use two or more concepts well integrated. The reporting to another group stimulates students' discussions. The SOLOtaxonomy makes it possible to assess group learning and interaction in lab groups.
\end{abstract}

Keywords: Chemistry, Lab work, Lower Secondary School, Solo-Taxonomy, Using Science Knowledge

\section{BACKGROUND, AIMS AND FRAMEWORK}

The aim of this project is to study students' science learning by investigating their ability to use science knowledge when talking about laboratory experiments that they carry out. The framework for learning involves both individual construction of knowledge and social interaction between individuals and that understanding emanates from social interaction.

Practical work is according to Jenkins (1999) an important element in science education and is important for students' learning. Jenkins argues that working with concrete materials can give the students a feeling for the phenomena that can help them to understand how difficult it is to obtain knowledge about the natural

Correspondence to: Olle Eskilsson, PhD.

Department of Mathematics and Science, Kristianstad

University, Kristianstad, SE-291 88 Sweden

E-mail:olle.eskilsson@telia.com world. He means that it is easier to learn about the natural world by using practical work. According to Jenkins practical work in school science should involve more discussions about planning an investigation, realizing, data collecting and interpreting. White (1996) also talks about students using science knowledge but he means that there is a risk that students miss the links between the theoretical and the practical education. The aim of laboratory lessons is to support meaningful learning by complementing theories and to stimulate development of analytical and critical capacity (Lazarovitz \& Tamir, 1994).

The science classroom environment is very difficult to catch and many research projects on the relationship between students' achievement and the quality of learning environment in classrooms have been carried out during several decades. Students' perceptions in the science laboratory were approached by a group of science educators in Australia, who developed and validated the Science Laboratory Environment Inventory 
(SLEI) (Fraser, McRobbie, \& Giddings, 1993). This instrument consists of five learning environment scales: cohesiveness, open-endness, integration, rule clarity, and material environment. These scales were found to be sensitive to different approaches to laboratory work and in different science subjects. The SLEI has been used in several studies conducted in different parts of the world.

The CLES (Taylor, Fraser, \& Fisher, 1997) is another learning environment instrument that enable teacher-researchers to monitor their development of constructivist approaches to teaching.

The research on learning environment in both Western and non-Western countries has been focused on using questionnaires that assess students' perceptions of their classroom learning environment. Fraser (2006) sums up the implications for science education from such studies:

- Measures of learning outcomes alone cannot give a complete picture of the educational process in the classroom

- More feedback from students about classrooms should be used

- Science teachers should strive to use research results to develop learning environments

- Evaluation of new curricula should include classroom learning environment instruments.

Fraser shows a wide field of application for using learning environment assessment for research as well as practical purpose. He also proposes international projects with new questionnaires that tap nuances and uniqueness of classrooms in particular countries. Fraser means that the next generation of learning environment studies could benefit from new methods of data analysis.

In an European project on lab work Millar et al (2002) want to investigate the effectiveness of lab work for achieving the goals. One aim of science education and the lab work activities is to help students develop their understanding of the natural world. In this project they are studying the varieties and the effectiveness of lab work in school science teaching. They present a profile of a lab work task that could be used to analyze instructions for and student's activities during lab work activities. The coding scheme has the following aspects:

- Intended learning outcome

- The cognitive structure of the task.

Millar et al find a wide field of application for the coding schemes they used in this project:

- Producing a detailed description of lab work tasks

- Comparing differences and similarities in lab work tasks
- Comparing types of lab work tasks used with students of different ages and stages in different countries.

Lunetta, Hofstein \& Clough (2006) present an analysis of Research, Theory and Practice. They found among other things that there are both similarities and differences between the way the scientific community and the learners in school come to understand their world.

Tytler (2006) discusses science literacy from the aspect of developing science capabilities of citizens. He asks questions about how citizens use "science" in their daily lives and when discussing socio-scientific issues. He refers to studies with laymen, which show that meaningful science learning can occur when citizens interact with science in their lives. Tytler means that in school science we need to stress the nature of science and the way it operates. These studies must include more sophisticated versions of scientific investigations with focus on analytic thinking and problem solving, communication and creativity.

Language is according to Lemke (1990) the most important mechanism for developing, testing and communicating knowledge. He states that lab work offers unique possibilities for students to talk science to each other and to write notes on what they do.

Newton, Driver, \& Osborne (1999) describe a study where they tried to focus the communication pattern in a classroom. The study produces knowledge about what happens in the classroom in a broad sense. Lemke (2007) concludes that using knowledge demands deep understanding and a critical perspective. Deep understanding means both that you have examined the subject in depth and that you have looked at it from different perspectives. You must also be able to talk about it in many different ways. With critical perspective Lemke means thinking about both the subject and why the subject is studied.

Sutton (1998) describes learning science in school as 'learning to talk in new ways' and to use science knowledge when talking about everyday phenomena. Solomon (1983) describes it in a similar way when she says that students develop their ability to use new ways of explaining on an individual level, and that they then reorganise and reconstruct the new information on a social level. Tytler (2002) finds that if school science knowledge should be useful to the students, continual links must be made between school experiences and social uses of the science knowledge. Many researchers e.g. Eskilsson and Helldén (2003) mean that students use everyday language parallel to science language. Wells and Mejia-Arauz (2006) have found that there is increasing agreement among those studying classroom activities that learning is likely to be most effective when students are actively involved in the dialogic construction of meanings that are significant for them. 
Ann L. Brown et al (1997) and Mercer (1996) conclude that students have to learn strategies for successful learning and that they have to learn about how to cooperate. The teachers can foster certain discourses. Mercer's and Brown's papers have inspired this study. Brown et al initiate a research program FCL, Fostering Communities of Learners, with four key ideas: agency, reflection, collaboration and culture. Propitious conditions for productive discussions involve students talking to each other, solving problems, and that working together is stimulated. Reciprocal teaching groups are designed to help students to monitor their comprehension. Brown et al discuss why students not are aware of their learning strategies. She claims that students need to learn how to learn and she focuses a/ remembering and b/ monitoring. She uses Bruner's (1996) four concepts for good learning environments: agency, reflection, collaboration and culture. A focus in the learning culture was to make learning development clear for the students. Brown states that FCL was more and more influenced by Vygotskyan theories during the project. Mercer too means that students have to learn more about collaboration. Favourable conditions for fruitful discussions involve that teachers must stimulate students to talk to each other when solving a problem. Tytler (2006) too discuses engaging the science learners and concludes that the ways in which teachers shape communities of learners and develop the science language are stressed by sociocultural approaches.

Mercer (1995) studies students' talk and finds three ways of talking and thinking:

- Disputational talk: disagreement and individual decision-making, challenge

- Cumulative talk: speakers build positively but uncritically on what the other has said.

Repetition, confirmation and elaboration

- Explorative talk: engage critically but constructively with each other's ideas.

Vygotsky's theories have in comparison with Piaget's theories more room for teachers' as well as learners' construction of knowledge as a joint achievement. Vygotsky provides us with a theory of the development of thought and language.

Hofstein (2004) summarizes new information based on scholarly research about laboratory work. He means that school laboratory activities have special potential as media for learning. The teachers need knowledge about enabling students to interact intellectually and physically - both in hands-on work and minds-on reflection. Nakhleh, Polles, and Malina (2002) mean that there is need for more research about assessing group learning and interaction during lab work and about students' perspectives on lab work.
Table 1. Categories in the SOLO-taxonomy (Biggs \& Collis, 1982)

P: Prestructural - bits of unconnected and inadequate information

U: Unistructural - focus on one relevant domain, simple connections can be made

M: Multistructural - pick up more than one relevant feature, no integration

R: Relational - integration between relevant data, relations to the whole

E: Extended abstract - can generalise and transfer the principles and ideas

\section{METHODS AND SAMPLES}

The research-questions for the present study are:

- How do students' discussions during lab work stimulate learning science in the group?

- How can stimulated interaction have an influence on students' use of science knowledge?

This study is based on Brown's et al (1997) FCL project and is part of a two-year study on learning and communication in science classrooms involving 25 students aged 14-15 years. The intervention in this unit concerns students working in groups of three, where one of them is chairperson, one is secretary, and one of the students prepares an oral report to another group. All the students in a group take part in the practical work.

Students' communication and learning is studied by analysing their use of scientific knowledge. The lessons are video recorded and in each group the discussions about the experiments are tape-recorded. The topics for the lab work studied are foodstuff chemistry. Half of the groups experiment with coagulating egg white protein that is a/ heated, b/ added an acid, and c/ added a solution of copper sulphate so that the protein coagulates. The others experiment with fats: grease spot as test for fats, and testing solvents for fats. Each group experimenting with fats then have to report to a group experimenting with proteins about what they have done and about their conclusions and vice versa.

Students' science talk in the video recordings and tape recordings are analyzed. The analysis is based on the SOLO-taxonomy (Structure of the Observed Learning Outcome) described by Biggs and Collis (1982) and later developed by them (1991).

Modified versions of the SOLO-taxonomy have also been used by e.g. Panizzon (2003) identifying cycles of students' understanding of diffusion, Tytler (1998) studying the structure of primary school students' explanations of air pressure, and Berg (2005) classifying the structural complexity in the responses from university students in chemistry. The modifications often are adjustment for the use of the taxonomy. 
Table 2. Categories used in this study accorting to a revised SOLO-taxonomy

\section{Category in the present study}

$\mathrm{U} 1 /$ describes the experimental prodecure

$\mathrm{U} 2 /$ mentions relevant concepts

$\mathrm{U} 3$ / comments on concrete as pects of phenomena

M4/ uses more than one relevant concept in a relevant way but no integration

$\mathrm{R} 5 /$ uses two or more concepts well integrated in a relevant way

R6/ all data is integrated
SOLO-category by Biggs and

Collis

Unistructural

Multistructural

Relational

Table 3. Examples from the discussions during the laboratory work

\section{T: Has the protein coagulated? \\ S1: When you mix hydrochloric acid in a protein it will coagulate. \\ T: What has coagulated? \\ S2: The protein \\ S3: Milk contains much protein and it coagulates with soured milk.}

When analyzing the discussions in the groups, these discussions are divided into sequences. In each sequence the students are discussing one separate part of the lab work activity. These sequences are analyzed using a version of the SOLO-taxonomy. See Table 2.

The focus of the study is students' use of their science knowledge. This revised version of the SOLOtaxonomy makes it possible to get information about the structure of students' use of science knowledge and of the quality of students' knowledge in the science conceptual area.

No categories corresponding to Prestructural and Extended abstract are used. These categories are not relevant in this study. The sequences categorized as Prestructural statements are not relevant for this subject field, since they do not show how students use their science knowledge. According to Extended abstract the students are supposed to formulate generalized principles, which they are not in this study. In some of the other categories sublevels have been formulated. All statements from the students originate from talking with other students or their teachers.

\section{RESULTS}

When students are doing lab work they talk about what they are doing and then they often use science knowledge and scientific concepts. In Table 3 there is one example from these discussions. Students' use of their scientific knowledge is marked in extra bold type.

\section{Talking during the experimental work}

\section{Many students: Lactic acid}

T: Soured milk has sour taste

S3: I do not like sour milk!

S2: (checks with T to see if she has understood) When they produce sour milk they use lactic acid in milk? $\mathrm{T}$ : Yes they put many lactic acid bacteria in the milk

The discussions then are divided up in sequences that have been analyzed. Examples from the categorization of parts of sequences using categories in Table 2:

S1: We will bring the egg white to boil.

S2: The egg white becomes white! (U1)

Students use one or more concepts.

Shall we take new protein? (U2)

Students are discussing what will happen in the experiments.

What will happen when we mix protein with an acid? How shall we do this experiment? (U3)

Many students use different aspects when talking about their experiments.

S3: How can we know when it will coagulate?

S4: We warm it and see what happens.

S3: It turns white - at a temperature of 60 to 70 degrees (M4)

Some students try to interpret the instruction and widen the discussion.

We should find out at which temperature the egg

white will coagulate. It is the same thing. (R5)

In one group the students describe how they examine if food contains fat.

If you put the food on a paper and then take it away, you will see if a spot will remain - then there is fat in the food (R6)

These SOLO categories have been used to analyze students' use of science knowledge during laboratory lessons.

The analysis of the discussions during lab work is summarized in Table 4. 
Table 4. Discussions during the lab work activities

\begin{tabular}{|c|c|c|c|}
\hline Group & SOLO-categories & Change of categories & Number of sequences \\
\hline$\overline{\mathrm{A}}$ & 4xU1. U3-R5 & Varying - falling & 11 \\
\hline B & 2xU1. U2-M4 & Falling & 6 \\
\hline $\mathrm{C}$ & 3xU1, U2-M4 & Constant & 9 \\
\hline $\mathrm{D}$ & 2xU1. U2-M4. & Increasing on every sub-experiment & 11 \\
\hline $\mathrm{E}$ & 3xU1. U2-R5 & Increasing on every sub-experiment & 10 \\
\hline $\mathrm{F}$ & 5xU1. U2-R6 & Increasing to high level many times & 15 \\
\hline G & 3xU1. U2-R5 & Increasing to R5 in each experiment & 18 \\
\hline $\mathrm{H}$ & 1xU1. U3-M4 & Increasing & 5 \\
\hline I & 3xU1. U2-U3 & Increasing & 8 \\
\hline
\end{tabular}

Table 5. The analysis of the discussions during the reporting to another group

\begin{tabular}{lllc}
\hline Group & SOLO-categories & Changing & Number of sequences \\
\hline I & U1- M4 & Increasing & 2 \\
II & U2 (discussion) -R5 & Increasing & 5 \\
III & M4-R5 & Even & 4 \\
IV & U1 (discussion)+3xR5 & Increasing & 6 \\
V & M4-R5 & Increasing & 3 \\
VI & M4-R6 & Increasing & 3 \\
VII & 2xR6 & Even & 2 \\
VIII & 2xU3-M4 & Falling & 4 \\
IX & R5-R6 & Increasing & 3 \\
\hline
\end{tabular}

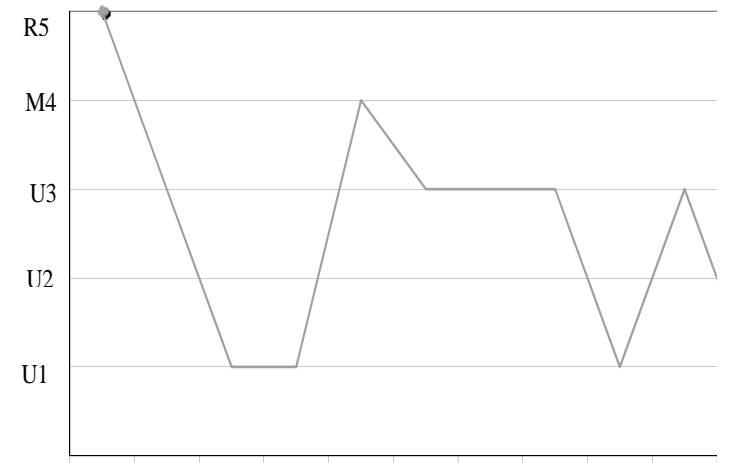

Figure 1 .Example from categorization group $B$

As an example the sequences from the discussions in group $\mathrm{E}$ are described: The sequences are categorized: U1, M4, U1, U2, R5, U3, U1, R5, M4, M4. 3xU1 means that there are three sections with descriptions of the experimental procedure. U2-R5 means that besides the $\mathrm{U} 1$ there are sections categorized U2, U3, M4 and R5. Change of categories is a short summary of the quality changes in the sequences. In this example "Increasing on every sub-experiment" means that in all three parts of the experiment the quality of the sequences increases.

Six of the nine groups had increasing quality of their science talk during the experiments. Many of the

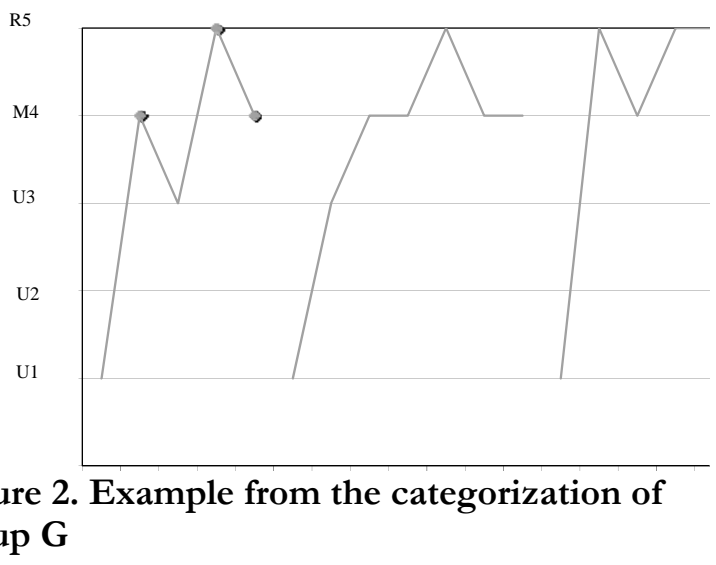

sequences had category U1 when they started with each sub experiment. Students used words and concepts introduced in the laboratory lesson as well as earlier introduced words. Five groups had at least 10 sequences identified. The students seemed to be stimulated to use science knowledge when doing lab work. There also were three groups with six or less sequences. This can be due to shy students or that they are not so sure in understanding the chemistry words used in the lesson

The time scale diagrams Fig. 1 and Fig. 2 describe categories during the experimental work.

$$
\text { 4xU1. U3-R5 Varying - falling }
$$


This group was experimenting with proteins. The sequences from the discussion were categorized in different categories. The long time trend seems to be falling to lower quality. The variation cannot be explained by working with new experiments.

3xU1. U2-R5 Increasing to $\mathrm{R} 5$ in each new experiment

This group was experimenting with proteins.

They have eighteen sequences analyzed and twelve of them are in M4 or R5 (multistructural or relational), which mean that they have high quality in their use of science knowledge. The group was very active. They only had one U1 in each sub experiment. Often this was from discussing the experimental procedure.

\section{Explaining to another group that has not done these experiments}

The reporting groups work in different ways. Some of them read from their papers and the other group write it down. In some groups there are many discussions and questions. Only a few sequences categorised U1-U3 can be found. The categories corresponding to structures of higher quality are more

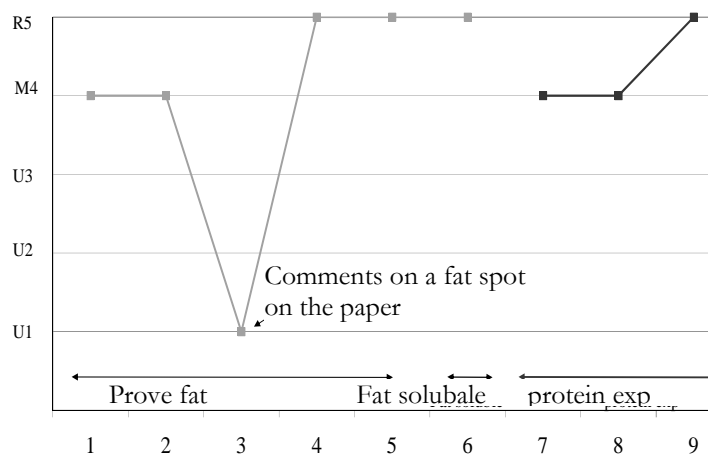

Figure 3. Analysis of sequences in the presentations - example A.

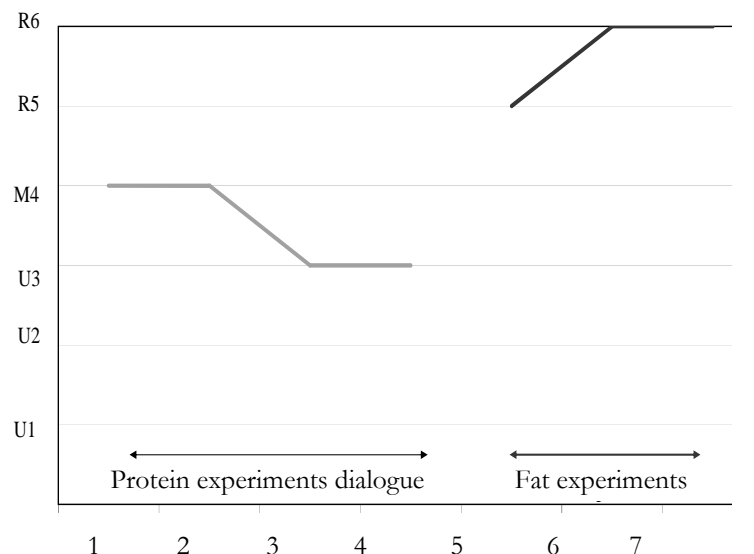

Figure 4. Analysis of sequences in the presentations - example B. common than during the lab work discussions. There are not so many categories in each reporting group. The intervention with ideas from Brown (1992) seems to stimulate students' ability and capacity to use science knowledge. All groups but one have R-categories. Almost $40 \%$ of the statements are analysed to Rcategories.

Here follows examples from students' use of science knowledge during the reporting to other students that have not done the same experiments (part of sequences):

Some students describe what happens.

The cooking oil and the butter: we get a spot of grease on the paper. (U1)

Other students use science concepts when they report about their experiments

We had to examine what happened with drops of water, butter and cooking oil on a paper. The water evaporated. (U2)

The students also refer to concrete aspects of the phenomena during the report

S5: What happens when you mix an acid and a protein?

S6: It will coagulate?

S5: Does everything coagulate?

S6: No not the protein in the eggs. (U3)

When talking about the experiments the students sometimes complete their results with comments on the substances

S7: How does heavy metals act on protein?

S8: The protein coagulates. It was protein mixed with water in the beginning. (M5)

The students try to integrate different concepts in a relevant way.

Petrol and acetone was the best and fat was not soluble in ethanol. (R5)

A few students can integrate and generalise all relevant different aspects.

We had to show how to identify fat. We put drops of the substances on a paper. If the spot remains it contains fat. (R6)

In the discussions after the experiments the students had to summarize what happened and their conclusions of the experiments to classmates that had not done the same experiments. The analysis then focused presenters and not the questions from the other students. See Table 5.

The quality of the students' use of science knowledge during their presentation, as analyzed with a revised Solo-taxonomy (Table 2), is higher in the presentation than in the lab work discussions. The students seem to learn to be sure in the use of their knowledge to a higher degree. In five of the presentations there only were three or less sequences analyzed. This can depend on that the students 
presented their results in bigger parts. In seven of the presentations there was at least one sequence analyzed as R5 or R6. In six of them the quality was increasing.

In figure 3 and figure 4 the analysis of some of these presentations is shown. In each diagram there are two graphs. One of the graphs shows the categorization of the presenting of the experiments with protein and the other the categorization of the presenting of the experiments with fats

\section{VIII: 2xU3-2xM4 Falling}

The presentation of the protein group is on $\mathrm{U} 3$ and M4 level. The downward tendency can depend on the content of discussion.

IX: R5-R6 Increasing

The analysis of the "fat group" presentation is on the multistructural or relational level all the time.

\section{IV: U1 (discussion) $+3 \times R 5 \quad$ Increasing}

The sequences in "fat group" presentation were analyzed multistructural or relational level all the time except on sequence 3 when the students' discussed a fat spot on the paper.

\section{$V: M 4-R 5$ Increasing}

The sequences of the presentations of the protein group were high and stable M4 or R5.

\section{CONCLUSIONS AND IMPLICATIONS}

The focus in this study is on group learning and interaction during lab work (Nakhleh, Polles, \& Malina, 2002) and how learning and interaction can be stimulated (A. L. Brown, Campione, Metz, \& Ash, 1997).

In the discussions about the experiments the students use science knowledge as well as everyday talk. They talk about the experimental procedure as well as the science content. Talking to each other during lab work as well as reporting to another group of students show how they can use science knowledge instead of everyday talk (Sutton, 1998).

The analysis with a revised SOLO-taxonomy was used to study only one aspect of students' perception in the school laboratory, how students use their science knowledge during lab work. The analysis also shows different learning environment aspects from the SLEIproject (Fraser, McRobbie, \& Giddings, 1993). In sequences analyzed as multistructural or relational the students talk about cohesiveness, open-endness, and integration. During the reporting to another group student's involvement become apparent. The analysis of students' use of science knowledge completes the picture of the educational processes in the classroom (Fraser (2006). The SOLO-taxonomy also perhaps could contribute to what Fraser (2006) call the new generation of learning environment studies. Many of the aspects described in "profile of a lab work task" (Millar, Tiberghien, \& Le Marechal, 2002) could be compared with the SOLO-analysis used in this project: e.g. the process of using data to support a conclusion, learning facts in chemistry, exploring relationship, accounting for observations, and testing predictions. The Millar et al profile can be used to improve the analysis with the revised SOLO-taxonomy.

Using the modified SOLO-taxonomy (Biggs \& Collis, 1982) makes it possible to study the quality of the students' science talk. The analysis of the discussions during the laboratory work shows a long-term development towards higher quality in most of the groups even if there also are some unistructural sequences. The intervention stimulates the students to use science knowledge. When having to report to another group the students focus their work on understanding the experiments and on preparing the presentation and when reporting they describe the experiment using new knowledge and new concepts. Almost all reporting groups use two or more concepts well integrated. This findings correspond to conclusions from other researchers (A. L. Brown, Campione, Metz, \& Ash, 1997; Bruner, 1960; J. L. Lemke, 1988). The teaching sequence could be followed up by Tytler's ideas of more sophisticated scientific investigations.

An analysis method like the SOLO-taxonomy could also be used to assess group learning and interaction in lab groups.

\section{REFERENCES}

Berg, A. (2005). Learning Chemistry at the University level. Students' attitudes, motivation, and design of learning environment. $\mathrm{PhD}$ Thesis. Umea University.

Biggs, J. B., \& Collis, K. F. (1982). Evaluating the quality of learning: the SOLO taxonomy. . New York: Academic press.

Biggs, J. B., \& Collis, K. F. (1991). Multimodal Learning and the Quality of Intelligent Behaviour. In H. A. H. Rowe (Ed.), Intelligence: Reconceptualisation and Measurement. Hillsdale, N.J.: Lawrence Erlbaum.

Brown, A. L. (1992). Design experiments: Theoretical and methodological challenges in creating complex interventions in classroom settings. The Journal of the Learning Sciences, 2(2), 141-178.

Brown, A. L., Campione, J. C., Metz, K. K., \& Ash, D. B. (1997). The Developing of Science Learning Abilities in Children. In K. Härnqvist \& A. Burgen (Eds.), Growing Up with Science (pp. 7-40). London: Jessica Kingsley Publishers.

Bruner, J. (1960). The Process of Education. Cambridge, Mass: Harvard University Press.

Bruner, J. (1996). The culture of education (2 ed.). Cambridge, Massachusetts: Harvard University Press.

Eskilsson, O., \& Helldén, G. (2003). A Longitudinal Study on 10-12-Year-Olds' Conceptions of the Transformations of Matter. Chemistry Education: Research And Practice, 4(3), 291-304.

Fraser, B. J., McRobbie, C. J., \& Giddings, G. J. (1993). Development and cross-national validation of the 
laboratory classroom environment for senior high school science. Science Education, 77(1), 1-24.

Fraser, B. J. (2006). Classroom Learning Environments. In S. K. Abell \& N. G. Lederman (Eds.), Handbook of Research on Science Education (pp. 103-124). Mahwah, New Jersey: Lawrence Erlbaum Associates.

Hofstein, A. (2004). The Laboratory In Chemistry Education: Thirty years of Experience with Developments, Implementation, and Research. Chemistry Education: Research and Practice, 5(3), 247-264

Jenkins, E. W. (1999). Practical work in School Science. In J. Leach \& A. Paulsen (Eds.), Practical Work in Science Education: Recent Research Studies (pp. 19-32). Roskilde: Roskilde University Press.

Lazarovitz, R., \& Tamir, P. (1994). Research on using laboratory instruction in science. In D. Gabel (Ed.), Handbook of research on science teaching and learning (pp. 94129). New York: Macmillan Publishing Company.

Lemke, J. (2007). Re-Engineering Education in America. Retrieved 0524, 2007, from http://wwwpersonal.umich.edu/ jaylemke/papers/Re-engineering Education.htm

Lemke, J. L. (1988). Analysis Verbal data: Principles, Methods and Problems. In B. J. Fraser \& K. G. Tobin (Eds.), International Handbook of Science Education (Vol. 2, pp. 1175-1189). Dordrecht: Kluwer Academic Publishers.

Lemke, J. L. (1990). Talking Science: Language, learning and values. Norwood: Ablex Publishing Corporation.

Lunetta, V. N., Hofstein, A., \& Clough, M. P. (2006). Learning and teaching in the School Science Laboratory: An Analysis of Research, Theory, and Practice. In S. K. Abell \& N. G. Lederman (Eds.), Handbook of Research on Science Education (pp. 393-441). Mahwah, New Jersey: Lawrence Erlbaum Associates.

Mercer, N. (1995). The guided Construction of Knowledge: Talk Amongst Teachers and Learners Clevedon, Philadelphia, Adelaide: Multilingual Matters LTD.

Mercer, N. (1996). The quality of talk in children's collaborative activity in the classroom. Learning and Instruction 6(4), 359-377.

Millar, R., Tiberghien, A., \& Le Marechal, J.-F. ( 2002). Varieties of labwork: A way of profiling labwork tasks. In D. Psillos \& H. Niedderer (Eds.), Teaching and learning in the science laboratory (Vol. 9-20). Dordrecht: Kluwer Academic Publ.

Nakhleh, M. B., Polles, J., \& Malina, E. (2002). Learning Chemistry in a Laboratory Environment. In J. K. Gilbert, O. D. Jong, R. Justi, D. F. Treagust \& J. M. V. Driel (Eds.), Chemical Education Towards Research-based Practice (pp. 69-94). Dordrecht: Kluwer Academics Publishers.

Newton, P., Driver, R. , \& Osborne, J. (1999). The place of argumentation in the pedagogy of school science. International Journal of Science Education, 21(5), 553-576.

Panizzon, D. (2003). Using a cognitive structural model to provide new insights into students' understandings of diffusion. International Journal of Science Education, 25(12), 1427-1450.

Sutton, C. (1998). New Perspectives on Language in Science. In K. G. Tobin \& B. J. Fraser (Eds.), International Handbook of Science Education I. Dordrecht: Kluwer Academic Publishers.
Taylor, P., Fraser, B., \& Fisher, D. (1997). Monitoring constructivist classroom learning environments. International Journal of Educational Research, 27(4), 293-302.

Tytler, R. (1998). Children's Conceptions of Air Pressure: Exploring the Nature of Conceptual Change. International Journal of Science Education, 20, 929-958.

Tytler, R. (2002). Teaching for understanding in science: Student conceptions research, and changing views of learning. Australian Science Teachers' Journal, 48(3), 14-21.

Tytler, R. (2006). Re-imagining Science Education. Engaging students in science for Australia's future. Victoria: Australian Council for Educational Research.

Wells, G., \& Mejia-Arauz, R. (2006). Dialogue in the classroom. The Journal of the Learning Sciences, 15(3), 379428.

White, R. T. (1996). The link between the laboratory and learning. International Journal of Science Education, 18(7), 761-774.

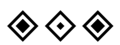

